\title{
Clinical Response of Inactive Ovaries in Dairy Cattle after PRID Treatment
}

\section{Victor Chisha ZULU1), Toshihiko NAKAO ${ }^{2)}$, Kyoji YAMADA ${ }^{2)}$, Masaharu MORIYOSHI'), Ken NAKADA ${ }^{1)}$ and Yutaka SAWAMUKAI ${ }^{1)}$}

${ }^{1)}$ Department of Obstetrics and Gynecology, Graduate School of Veterinary Medicine, Rakuno Gakuen University, 582 Bunkyodai-Midorimachi, Ebetsu-shi 069-8501, Hokkaido, and ${ }^{2)}$ Animal Science Laboratory, Graduate School for International Development \& Cooperation, Hiroshima University, Kagamiyama 1-5-1, Higashihiroshima-shi, Hiroshima-ken 739-8529, Japan

\begin{abstract}
The aim of this study was to evaluate the therapeutic effects and safety of progesterone releasing intravaginal device (PRID) in the treatment of inactive ovaries in dairy cattle. The possible influence of PRID on metabolic and/or health status was also examined. A total of 30 anestrous Holstein-Friesian cows, which on rectal palpation had small, flat and smooth or rounded ovaries were used for the experiment. PRID or placebos were inserted into the vagina and left in place for 12 days. Four animals lost the intravaginal device and one was culled. At the time of PRID insertion, the other 25 animals were divided in two groups: 18 with a progesterone concentration $\leq 1.0 \mathrm{ng} / \mathrm{ml}$ (group A), of which 16 were treated with PRID and 2 with placebos, and 7 with a progesterone concentration $>1.0$ $\mathrm{ng} / \mathrm{ml}$ (group B), of which 5 were treated with PRID and 2 with placebos. Of the 16 treated animals in group A, $8(50 \%)$ had a corpus luteum (CL) within 14 days after PRID removal. Of the 5 treated animals in group $\mathrm{B}, 3(60 \%)$ had a CL within 14 days after PRID removal. The mean interval from PRID removal to estrus was $2.7 \pm 0.3$ and $3.0 \pm 1.0$ days ( \pm SE) in group $A$ and $B$, respectively. The conception rate of cows in group A that recovered after treatment with PRID, was $28.6 \%$. No significant changes were observed in hematocrit $(\mathrm{Ht}), \mathrm{WBC}$ and serum levels of glucose, BUN, AST and ALT at the time of PRID insertion and removal, both within and between animals that recovered and those that did not. PRID is an effective treatment for inactive ovaries in dairy cattle and does not adversely affect metabolic and/or health status of animals. Further study is required to improve conception rate at the induced estrus.
\end{abstract}

Key words: Cow, Inactive ovaries, PRID.

(J. Reprod. Dev. 46: 415-422, 2000)

I nactive ovary (true anestrus) is a condition in which the ovaries are quiescent without signs of cyclicity or cycle related ovarian structures. The cow would not have shown any sign of estrus and rectal palpation reveals small ovaries, which are either flat and smooth or sometimes rounded if follicles are present [1]. The reasons for the failure

Accepted for publication: August 29, 2000

Correspondence: V. C. Zulu of normal ovarian activity may be insufficient release or production of gonadotropins to induce follicular development and maturation or it may reflect the failure of the ovaries to respond to gonadotropins. This condition is most frequently diagnosed in high-yielding dairy cows and first calf heifers. A number of factors predispose to the condition. A low level of nutritional intake has been considered to be a major cause [1]. Many 
cows also have this ovarian dysfunction during winter [1].

Reproductive performance is adversely affected by true anestrus. It causes prolonged intervals from calving to first estrus, first service and to conception [2]. It may also lead to an increase in the number of services per conception and reduction in conception rate [2].

Several hormonal preparations are available for induction of estrus in anestrous cows. These include estradiol, gonadotropin releasing hormone $(\mathrm{GnRH})$, luteinizing hormone $(\mathrm{LH})$, follicle stimulating hormone (FSH) and progesterone $[3,4]$. Estradiol causes release of GnRH from the hypothalamus and induces estrus [4]. GnRH causes release of $\mathrm{LH}$ and FSH from the anterior pituitary and initiates normal cyclicity, if GnRH injection is followed by maturation of follicles, ovulation and corpus luteum (CL) formation. LH and FSH directly act on the ovary to stimulate follicular growth and maturation leading to estrus. However, none of the above treatments has proved very useful for inducing estrus in anestrous cows under field conditions $[5,6]$. Recent studies indicate that progesterone may be the treatment of choice for inactive ovaries. The principle of this treatment is to mimic the ovarian cycle with progesterone favoring storage to release of gonadotrophins. This results in an LH surge and ovulation on termination of progesterone therapy. Progesterone also primes the brain for exhibiting behavioral estrus.

Progesterone releasing intravaginal device (PRID, Sanofi, Animal Health, France) is a stainless steel coil covered with an inert elastomer incorporating $1.55 \mathrm{~g}$ of progesterone and a $10 \mathrm{mg}$ capsule of estradiol benzoate.

PRID has been used for estrus synchronization, treatment of postpartum anestrus, cystic ovaries and other functional abnormalities in dairy cattle [7]. PRID has been successfully used to induce estrus with ovulation in anestrous animals, with conception rates ranging between 30 and $64 \%$ after treatment [8-14]. Another progesterone intravaginal device developed in New Zealand, controlled internal drug release (CIDR), induces estrus within 7 days after removal in anestrous cattle $[15,16]$. There are significant differences between herds in ovarian response patterns to CIDR. Rhodes et al. [16] reported a mean recovery of $87 \%$ (range $69-100 \%$ ) between herds while other studies observed that up to $50 \%$ of cows did not display heat nor ovulate after CIDR treatment [6, 15].

Induction of estrus and ovulation in anestrous dairy cattle still remains a great challenge for the veterinary practitioner. As outlined above, this is because of variable results obtained by using different hormonal preparations. Although progesterone has been used in the treatment of inactive ovaries [9], its mechanism of action has not been fully understood, and the results obtained are not consistent between herds [16]. Although some studies have reported on the use of PRID in treatment of inactive ovaries, repeat breeding, and estrus synchronization of cattle in Japan [17, 18], there is still need to investigate the therapeutic effects of PRID on inactive ovaries. The aim of this study was to evaluate the therapeutic effects and safety of PRID in the treatment of inactive ovaries in dairy cattle. To evaluate safety of the treatment, the possible influence of PRID on metabolic and/or health status was also examined.

\section{Materials and Methods}

\section{Animals}

The study was conducted in Hokkaido, the major dairy region of Japan, at two veterinary practices covering a total of over 30 dairy farms. The 30 Holstein-Friesian cattle, used for the study were aged between 2 and 8 years. Inactive ovaries were diagnosed by palpation per rectum. Cows included in the study were not observed in estrus for over one month and had small ovaries, which were either flat and smooth or rounded on rectal palpation. Most farmers kept their animals in either stanchions or freestall barns with a few on ranches. In addition to silage, hay and concentrates the animals were allowed to graze during spring, summer and autumn. The average milk yield per cow on the day of diagnosis was $27.4 \pm 1.9 \mathrm{~kg}$ ( $\mathrm{n}=$ 27). Calving was throughout the year, and breeding started after 60 days postpartum. Cows were artificially inseminated.

The cows were in fair or good body condition, healthy, eating well, and had no history of other reproductive problems. No treatment with other hormones was given within the last 2 months. The animals calved between March 1997 and October 1998 and at the time of treatment the mean $( \pm$ SE) 


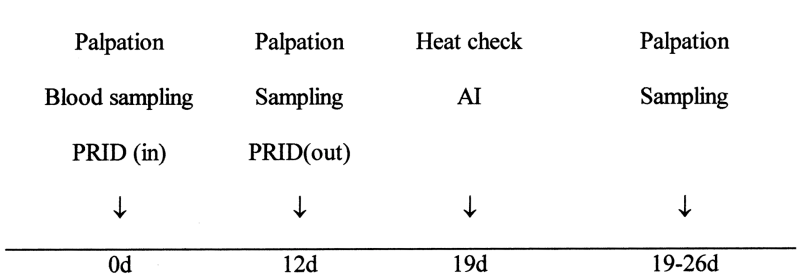

Fig. 1. Experimental procedure for PRID treatment in cows with inactive ovaries.

0 d: Day of PRID insertion. 12 d: Day of PRID removal. $19 \mathrm{~d}$ : Day of Heat check. 19-26 d: Day of CL check.

number of days after calving was $81.6 \pm 5.0$ days (range 60-180).

\section{Treatment protocol}

A summary of the experimental procedure is shown in Fig. 1. A PRID with a $10 \mathrm{mg}$ estradiol capsule or placebo (a coil like PRID without progesterone or estradiol capsule) was inserted into the vagina by hand after disinfecting the surgeons' arms and vulva area and left in place for 12 days. Within 7 days after PRID removal the cows were observed for estrus and artificially inseminated once or twice after detection of estrus and on the subsequent estrus if the animal was not pregnant. All cows were examined for the presence of a CL 14-16 days after PRID removal. To determine the stage of the estrous cycle, visual examination of the external genitalia, vaginoscopic examination of the vagina and external cervical orifice and palpation of the ovaries and uterus per rectum were conducted. Pregnancy diagnosis was carried out 35 days or more after AI by palpation per rectum.

\section{Sampling and analysis}

Blood samples were collected from the coccygeal vessels into two test tubes; one containing heparin for plasma and the other plain for serum on the days of PRID/placebo insertion, removal and CL diagnosis. After collection, blood samples were stored at $4 \mathrm{C}$ for 20-24 hours and then centrifuged at $1,700 \times \mathrm{g}$ for 20 minutes. Serum was decanted and either stored at $-20 \mathrm{C}$ for less than a month or immediately analyzed for glucose (GLU), blood urea nitrogen (BUN), aspartate aminotransferase (AST) and alanine aminotransferase (ALT). Heparinised blood samples were centrifuged at $1,700 \times \mathrm{g}$ for 20 minutes and, plasma was decanted and stored at $-20 \mathrm{C}$ until measurement of progesterone (P4). Heparinised blood samples were also used to determine hematocrit $(\mathrm{Ht})$ and total white blood cell count (WBC). GLU, BUN, AST, ALT, Ht and WBC were determined two times, on day of insertion and removal of PRID or placebo.

Plasma P4 concentrations were determined after a diethyl-ether extraction using a double antibody enzyme immunoassay kit (Kambegawa Laboratory, Tokyo) on microtiter plates coated with second antibody. The assay used anti-rabbit IgG goat antibody coated on the plates, progesterone-3caboxymethyl oximino-horse radish peroxidase as a tracer and rabbit anti progesterone-3(E)caboxymethyl oximino-BSA IgG. The inter- and intra-assay coefficients of variation were $11.2 \%$ and $6.5 \%$, respectively, at a concentration of $1.7 \mathrm{ng} / \mathrm{ml}$.

To determine $\mathrm{Ht}$, heparinised blood was aspirated in a capillary tube, centrifuged for 5 minutes at 12,000 rpm and read on an Ht scale. WBC, GLU, BUN, AST and ALT were determined at a commercial laboratory using biochemical autoanalyzers, SE9000 Sysmex (Tokyo, Japan.) for WBC, Hitachi 736 (Tokyo, Japan.) for GLU, BUN, AST and ALT.

\section{Evaluation of treatment}

A positive ovarian response to treatment or recovery was defined as occurrence of estrus within 7 days and formation of a CL 7-14 days after PRID removal. Animals in which estrus was not detected but a CL was palpated per rectum 14-16 days after PRID removal were also considered to have a positive response to the treatment. A negative ovarian response or no recovery was defined as absence of both estrus within 7 days and CL 16 days after PRID removal, or estrus within 7 days but no CL 16 days after PRID removal.

\section{Statistical analysis}

Fisher's Exact Test was used to test for the difference between two sample proportions. For normally distributed data, Student's t-test or its modification, the Welch t-test, was used to test for the difference between two sample means. The Mann-Whitney U test was used for not normally distributed data. Confidence interval analysis was used to confirm the results of the t-test and MannWhitney U-test. Differences were considered to be significant at $\mathrm{p}<0.05$. 
Table 1. Recovery and reproductive performance in cows with inactive ovaries after PRID treatment

\begin{tabular}{lccc}
\hline & \multicolumn{2}{c}{ Plasma Progesterone before treatment } & \multirow{2}{*}{ Total } \\
\cline { 2 - 3 } & $(\leq 1.0 \mathrm{ng} / \mathrm{ml}$ & $>1.0 \mathrm{ng} / \mathrm{ml}$ & \\
\cline { 2 - 3 } Number of cows treated & 165 & 21 & 9 \\
A: Estrus within 7 days and CL & 7 & 2 & 2 \\
B: No estrus but CL & 1 & 1 & $11(52.4 \%)$ \\
Recovered: A + B & $8(50 \%)$ & $3(60 \%)$ & $2.8 \pm 0.3$ \\
Days to estrus & $2.7 \pm 0.3$ & $3.0 \pm 1.0$ & $47.6(10)$ \\
\% inseminated & $43.7(7)^{*}$ & $60(3)$ & $10(1)$ \\
\% conceived after 1 $1^{\text {st }}$ AI & $14.2(1)$ & 0 & 1 \\
Conceived subsequently & 1 & 0 & $20.0(2)$ \\
\%Total conceived & $28.6(2)$ & 0 & $13 \pm 11$ \\
Days to conception (mean $\pm \mathrm{SE})$ & $13 \pm 11$ & 0 & \\
\hline
\end{tabular}

${ }^{*}$ Number of cows inseminated after PRID treatment.

Table 2. Plasma progesterone pattern in cows with inactive ovaries (day 0: Progesterone $\leq 1 \mathrm{ng} / \mathrm{ml}$ ) after PRID treatment

Progesterone Pattern
Day

\section{Results}

\section{Recovery and reproductive performance after PRID}

Of the 30 animals, 4 cows lost PRIDs during the 12-day insertion period, and one was culled during the experimental period due to very high milk somatic cell counts. These five cows were therefore excluded from further analysis. Based on the P4 concentration at the time of PRID insertion, the other 25 animals were divided in two groups, A and B. Group A consisted of 18 cows with P4 $\leq 1.0$ $\mathrm{ng} / \mathrm{ml}$, of which 16 were treated with PRID and 2 with placebos and group B consisted of 7 cows with P4 $>1.0 \mathrm{ng} / \mathrm{ml}$, of which 5 were treated with PRID and 2 with placebos.

Recovery and reproductive performance after treatment with PRID is summarized in Table 1. Of the 16 treated cows in group A, $7(43.7 \%)$ cows displayed estrus with formation of $\mathrm{CL}$, and one other cow did not show estrus but CL was detected 14 days after PRID removal. Thus, the recovery rate after PRID treatment in cows with progesterone concentration $\leq 1.0 \mathrm{ng} / \mathrm{ml}$ was $50 \%$. The mean $( \pm$ SE) number of days from PRID removal to estrus was $2.7 \pm 0.3$. 
Table 3. Plasma progesterone pattern in cows with inactive ovaries (day 0: Progesterone $>1 \mathrm{ng} / \mathrm{ml}$ ) after PRID treatment

Response to PRID treatment
Progesterone Pattern

Table 4. Blood parameters in cows with $\leq 1 \mathrm{ng} / \mathrm{ml}$ progesterone concentration at the time of PRID insertion

\begin{tabular}{|c|c|c|c|c|}
\hline \multirow[t]{2}{*}{ Items } & \multicolumn{2}{|c|}{$\begin{array}{l}\text { Positive response } \\
(\text { Mean } \pm \mathrm{SE})(\mathrm{N}=8)\end{array}$} & \multicolumn{2}{|c|}{$\begin{array}{l}\text { Negative response } \\
(\text { Mean } \pm \mathrm{SE})(\mathrm{N}=7)\end{array}$} \\
\hline & PRID IN & PRID OUT & PRID IN & PRID OUT \\
\hline $\mathrm{Ht}(\%)$ & $26.73 \pm 0.95$ & $28.03 \pm 0.72$ & $27.27 \pm 0.85$ & $28.58 \pm 0.83$ \\
\hline WBC $\left(10^{3} / \mathrm{mm}^{3}\right)$ & $7.60 \pm 0.89$ & $7.3 \pm 0.46$ & $7.27 \pm 0.51$ & $8.58 \pm 1.05$ \\
\hline GLU (mg/dl) & $65.25 \pm 2.47$ & $65.87 \pm 2.20$ & $62.14 \pm 2.28$ & $64.85 \pm 3.29$ \\
\hline BUN (mg/dl) & $15.18 \pm 1.33$ & $15.08 \pm 1.34$ & $16.92 \pm 1.91$ & $16.65 \pm 1.88$ \\
\hline AST(IU/l) & $72.13 \pm 4.36$ & $78.88 \pm 3.82$ & $74.85 \pm 5.00$ & $78.28 \pm 4.25$ \\
\hline ALT(IU / l) & $22.94 \pm 1.77$ & $25.00 \pm 1.57$ & $25.71 \pm 2.32$ & $28.28 \pm 1.93$ \\
\hline
\end{tabular}

Positive response: Estrus within 7 days and/or CL by 14-16 days after PRID removal.

Negative response: No estrus within 7 days and/or CL by 14-16 days after PRID removal.

Of the 5 treated cows in group B, 2 displayed estrus with the formation of a CL and one cow had a CL without estrus 14 days after PRID removal. Thus, the recovery rate after PRID treatment in cows with $\mathrm{P} 4$ concentration $>1.0 \mathrm{ng} / \mathrm{ml}$ was $60 \%$. The mean $( \pm$ SE) days from PRID removal to heat was $3.0 \pm 1.0$. There was no significant difference between groups A (50\%) and B (60\%) in the recovery rate.

Of the 2 cows treated with placebos in group A, one cow displayed estrus with formation of CL. None of the 2 cows treated with placebos in group B, displayed estrus or had CL 14 days after placebo removal. There was no significant difference in recovery rates in both groups $\mathrm{A}$ and $\mathrm{B}$, when compared to their respective controls. Overall, the recovery rate in the treated group $(52.4 \%)$ was higher than that in the control group (25\%), although no significant difference was found.

There was a little pus in the vagina in one of the 25 animals on removal of PRID, but there was no foul smell and no treatment was required.

Pregnancy rate in cows of group A with a positive response after treatment was $28.6 \%$ (Table $1)$.

\section{Plasma progesterone profile}

Plasma P4 pattern in cows with inactive ovaries treated with PRID is shown in Tables 2 and 3. In the cows that had a positive response after 
Table 5. Blood parameters in cows with $>1 \mathrm{ng} / \mathrm{ml}$ progesterone concentration at the time of PRID insertion

\begin{tabular}{lccccc}
\hline \multirow{2}{*}{\multicolumn{1}{c}{ Items }} & \multicolumn{2}{c}{$\begin{array}{c}\text { Positive response } \\
\text { (Mean } \pm \text { SE) }(\mathrm{N}=2)\end{array}$} & & \multicolumn{2}{c}{$\begin{array}{c}\text { Negative response } \\
\text { (Mean } \pm \text { SE) }\end{array}$} \\
\cline { 2 - 3 } \cline { 5 - 6 } & PRID IN & PRID OUT & PRID IN & PRID OUT \\
\cline { 2 - 3 } & $27.4 \pm 2.4$ & $27.6 \pm 2.6$ & & $30.95 \pm 0.85$ & $30.75 \pm 1.25$ \\
$\mathrm{Ht}(\%)$ & $6.6 \pm 1.5$ & $7.0 \pm 0.3$ & & $7.75 \pm 1.05$ & $7.85 \pm 0.85$ \\
$\mathrm{WBC}\left(10^{3} / \mathrm{mm}^{3}\right)$ & $65.5 \pm 1.5$ & $63.0 \pm 1.0$ & & $74.0 \pm 3.0$ & $71.5 \pm 0.5$ \\
$\mathrm{GLU}(\mathrm{mg} / \mathrm{dl})$ & $22.4 \pm 6.4$ & $20.75 \pm 2.45$ & & $17.15 \pm 7.85$ & $16.45 \pm 7.75$ \\
$\mathrm{BUN}(\mathrm{mg} / \mathrm{dl})$ & $66.0 \pm 9.0$ & $65.0 \pm 3.0$ & & $91.0 \pm 9.0$ & $89.0 \pm 6.0$ \\
$\mathrm{AST}(\mathrm{IU} / \mathrm{l})$ & $21.5 \pm 3.5$ & $23.0 \pm 2.0$ & & $30.5 \pm 0.5$ & $30.0 \pm 0.0$ \\
ALT $(\mathrm{IU} / \mathrm{l})$ & & &
\end{tabular}

Positive response: Estrus within 7 days and/or CL by 14-16 days after PRID removal.

Negative response: No estrus within 7 days and/or CL by 14-16 days after PRID removal.

treatment, on the day of PRID removal, 5 (31.2\%) and $2(40 \%)$ cows, in the groups with day $0 \mathrm{P} 4$ concentration $\leq 1.0 \mathrm{ng} / \mathrm{ml}$ and $>1.0 \mathrm{ng} / \mathrm{ml}$, respectively, had $\mathrm{P} 4$ concentration $\leq 1.0 \mathrm{ng} / \mathrm{ml}$. This showed that plasma P4 concentration was low in $7(63.6 \%)$ of the cows that had a positive response after treatment with PRID. At the time of detection of CL (day 19 to 26), all the cows that had a positive response in both groups, had plasma $\mathrm{P} 4$ concentration $>1.0 \mathrm{ng} / \mathrm{ml}$, thus confirming the diagnosis of an active CL.

In the cows that had a negative response after treatment, on the day of PRID removal, 4 (25\%) and $1(20 \%)$ cows, in the groups with day $0 \mathrm{P} 4$ concentration $\leq 1.0 \mathrm{ng} / \mathrm{ml}$ and $>1.0 \mathrm{ng} / \mathrm{ml}$, respectively, had progesterone concentration $\leq 1.0$ $\mathrm{ng} / \mathrm{ml}$. At the time of CL detection (days 19 to 26), all the cows that had a negative response in both groups, plasma P4 concentration was $\leq 1.0 \mathrm{ng} / \mathrm{ml}$, thus confirming the absence of an active CL. In both groups, day $0 \mathrm{P} 4$ concentration $\leq 1.0 \mathrm{ng} / \mathrm{ml}$ and $>1.0 \mathrm{ng} / \mathrm{ml}$, there was no significant difference between recovered and non-recovered cows in the number of cows that had plasma $\mathrm{P} 4 \leq 1.0 \mathrm{ng} / \mathrm{ml}$ on the day of PRID removal.

\section{Blood parameters before and after PRID}

For both groups $A$ and $B$, there were no significant changes in $\mathrm{Ht}, \mathrm{WBC}, \mathrm{GLU}, \mathrm{BUN}, \mathrm{AST}$ and ALT after PRID treatment. This was observed in both cows with positive and negative responses. Furthermore, there were also no significant changes observed in these parameters between cows that had a positive response and those that had a negative response.

\section{Discussion}

Progestagens have been shown to induce estrus in acyclic cows, and inactive ovaries can be effectively treated with PRID [4, 15, 19, 20].

In this study $50 \%$ and $60 \%$ of cows with $\leq 1 \mathrm{ng} / \mathrm{ml}$ and $>1 \mathrm{ng} / \mathrm{ml} \mathrm{P} 4$ concentrations at the time of PRID insertion, respectively, ovulated after PRID treatment. Dolezel et al. [11] reported a similar recovery rate of $60 \%$ after PRID treatment. Bulman et al. [10] reported $88 \%$ of cows with inactive ovaries ovulated after PRID treatment. Recovery rate can be improved, if gonadotropin such as eCG is given at the time of PRID removal. Roche \& Mihm [4] reported that an injection of 400-700iu eCG, given at the end of a 7-12 day progesterone treatment, increased the number of anestrous cows responding. Studies in New Zealand [15, 21, 22] have also shown that an injection of $600 \mu \mathrm{g}-1 \mathrm{mg}$ estradiol at 24-48 hours after a 5-7 day period of progesterone priming during the early postpartum period, increased the incidence of estrus with ovulation.

The Recovery rate observed in this study agrees with the results of Jubb et al. [6] who reported that $47 \%$ of anestrous cows exhibited estrus within 21 days after 7 days of CIDR and an injection of eCG at device removal. However, Rhodes et al. [16], reported a mean recovery rate of $87.1 \%$ after treating anestrous animals with CIDR for 6 days and an injection of estradiol 24 hours after CIDR removal. Gonzalez et al. [23], reported that $80 \%$ of cows with inactive ovaries treated with GnRH exhibited estrus after a mean of $17.5 \pm 2.3$ days. Kang et al. [24] reported only $40 \%$ of dairy cows with inactive ovaries had high progesterone 
concentration 12 days after treatment with GnRH. Ball and Lamming [5] concluded that GnRH was less effective than PRID treatment in lactating dairy cows with ovarian acyclicity.

The conception rate $(28.6 \%)$ after PRID treatment in this study was similar to $30 \%$ reported by Unal et al. [14], in anestrous cows after PRID treatment for 14 days, and lower than that $(60 \%)$ obtained by Forland et al. [12], after 2 inseminations. Rhodes et al. [16] reported a conception rate of $42.2 \%$, ranging from 26.8 to $61.9 \%$ in anovulatory anestrous animals within 7 days after treatment with CIDR and estradiol injection after device removal. Conception rate is also low in cycling cows after progesterone treatment for estrus synchronization $[15,25,26]$. Wright et al. [20] suggested that long term treatment (14-20 days) results in lower fertility because of inadequate sperm transport, disordered hormone secretion or patterns of follicular development, and retarded embryo development. The poor conception rate observed in this study could be attributed to the fact that the cows were not cycling at the time of treatment with PRID. PRID treatment leads to a plasma progesterone concentration lower than luteal phase concentration [27, 28]. This sub-luteal progesterone concentration does not adequately suppress LH secretion and therefore the dominant follicle (DF) continues to grow $[27,28]$. At PRID withdrawal the DF ovulates aged oocytes.

No significant changes were observed in $\mathrm{Ht}$, WBC and serum levels of GLU, BUN, AST and ALT after treatment with PRID. This suggests that PRID does not affect metabolic and or health status, and is therefore very safe for use in dairy cows. Furthermore, there were no side effects except for one cow with a little vaginal pus discharge, but no treatment was required.

There is still need for further research on treatment of inactive ovaries with hormones, taking into account management factors. In order to understand the mechanism of action in PRID treatment of inactive ovaries, frequent monitoring of the ovaries using ultrasonography, coupled with $\mathrm{LH}, \mathrm{FSH}$, estradiol and progesterone profiles is necessary. This may also help explain the poor conception rates obtained after the present PRID treatment.

In conclusion, PRID is an effective treatment for inactive ovaries in dairy cattle although conception rate is low. To further improve the recovery and conception rate after PRID treatment, it may be recommended to reduce the insertion period of PRID, combined with an injection of eCG or GnRH 24-48 hours after PRID removal.

\section{Acknowledgements}

The authors are greatly indebted to the Veterinary Surgeons at Shamou NOSAI, Koshimizu Veterinary Clinic and Nemuro NOSAI, Nakashunbetsu Veterinary Clinic, Hokkaido, Japan for carrying out the field trials.

\section{References}

1. Noakes DE. Functional forms of infertility. In: Arthur GH, Noakes DE, Pearson H, Parkinson TJ (eds.), Veterinary Reproduction \& Obstetrics. London, Philadelphia, Toronto, Sydney, Tokyo: W. B. Saunders Company Ltd.; 1996: 356-371.

2. Stevenson JS, Call EP. Reproductive disorders in the periparturient dairy cow. J Dairy Sci 1988; 71: 2572-2583.

3. Hopkins SM. In: Morrow DA (ed.), Current Therapy in Theriogelogy. Philadelphia: W.B. Saunders; 1986: 247-250.

4. Roche JF, Mihm M. Physiology and practice of induction and control of oestrus in cattle. In: xix World Buiatrics Congress Proceedings; 1996; Edinburgh, Scotland. Vol. 1: 157-163.

5. Ball PJH, Lamming GE. Diagnosis of ovarian acyclicity in lactating dairy cows and evaluation of treatment with gonadotrophin-releasing hormone or a progesterone releasing intravaginal device. Brit Vet J 1983; 139: 522-527.

6. Jubb TF, Brightling P, Malmo J, Larcombe MT, Anderson GA, Hides SJ. Evaluation of a regimen using a progesterone releasing intravaginal device (CIDR) and PMSG as a treatment for post partum anoestrus in dairy cattle. Aust Vet J 1989; 66: 334336.

7. Jeffcoate IA, Ayliffe TR. An ultrasonographic study of bovine cystic ovarian disease and its treatment. Vet Rec 1995; 136: 406-410.

8. Alanko $\mathbf{M}$, Pyorala $\mathbf{S}$. The treatment of anoestrus and suboestrus in dairy cattle using a progesterone releasing intravaginal device or gonadotrophins. 
Nordisk Veterinaer Medicin 1980; 32: 444-452.

9. Arbeiter K, Phol W. Use of the PRID spiral for treating inactive ovaries in cows. Second field trial. Tierarztliche Umschau 1986; 41: 664-668.

10. Bulman DC, McKibbin PE, Appleyard WT, Lamming GE. Effect of a progesterone releasing intravaginal device on the milk progesterone levels, vaginal flora, milk yield and fertility of cyclic and non-cyclic dairy cows. J Reprod Fert 1978; 53: 289296.

11. Dolezel R, Chech S, Zajic J. Follicular development during the progesterone therapy of ovarian acyclicity and ovarian cysts in cows Veterinarni Medicina 1998; 43: 145-151.

12. Forland DM. Treatment of anoestrous cattle with an intravaginal device that releases progesterone. Norsk Veterinaertidsskrift 1981; 93: 339-342.

13. Rusch $\mathbf{P}$, Berchtold M, Thun R, Hauser B. Ovarian and vaginal changes in anoestrous cows after treatment with progesterone releasing intravaginal device. Schweizer Archiv fur Tierheilkunde 1983; 125: 119-127.

14. Unal EF, Gockcen H, Nak Y, Tumen H. Treatment of anoestrus in cows and heifers with PRID (progesterone releasing intravaginal device). Veteriner Fakultesi Dergishi, Uludag Universitesi 1992; 11: 91-100.

15. Macmillan KL, Peterson AJ. A new intravaginal progesterone releasing device for cattle (CIDR-B) for oestrous synchronisation, increasing pregnancy rates and the treatment of postpartum anoestrus. Animl Reprod Sci 1993; 33: 1-25.

16. Rhodes FM, Clark BA, Nation DP, Taufa VK, Day ML, Macmillan KL, MacDougall S. Treatment of postpartum anoestrus in New Zealand dairy cows with progesterone an oestradiol benzoate. In: XX World Buiatrics Congress, Proceedings; 1998; Sydney, Australia. Vol. 2: 607-610.

17. Fukui Y, Kobayashi M, Tsubaki M, Kikuchi, N, Ono H. Regulating estrus and therapy of repeatbreeder and anestrous Holstein heifers using progesterone releasing intravaginal devices (PRID). Jpn J Vet Sci 1985; 47: 943-950.

18. Fukui $\mathbf{Y}$, Mutoh K, Tsubaki M, Odagiri I, Masuto $\mathbf{Y}$, Ono $\mathbf{H}$, Yagura $\mathbf{H}$. The use of a progesterone releasing intravaginal device (PRID) on synchronization of estrus in Japanese Black cattle. Jpn J Anim Reprod 1984; 30: 117-126.
19. Galloway DB, Brightling P, Malmo J, Anderson GA, Larcombe MT, Wright PJ. A clinical trial using a regimen which includes a norgestomet implant and norgestoment plus oestradiol valerate injection as a treatment for anoestrus in dairy cows. Aust Vet J 1987; 64: 187-189.

20. Wright PJ, Malmo J. Pharmacologic manipulation of fertility. Veterinary Clinics of North America: Food Animal Practice 1992; 8: 56-89.

21. Macmillan KL, McDougall S, Taufa VK, Day AM. Ovulation and oestrus among dairy cows with anovulatory anoestrus following progesterone treatment. Proceedings of the Australian Society for Reproductive Biology 1994; 26: 74.

22. McDougall $S$, Burke CR, Macmillan $K L$, Williamson NB. The effect of pretreatment with progesterone on the oestrous response to oestradiol$17 \beta$ benzoate in the postpartum dairy cow. Proceedings of the New Zealand Society of Animal Production 1992; 52: 157-160.

23. Gonzalez SC. Use of a GnRH analogue for problem cows and at the time of first insemination. In: Proceedings of the 8th Meeting of the Latin American Association of Animal Production; 1981; Dominican Republic. :129.

24. Kang BK, Choi HS, Son CH, Oh KS, Kang HK, Kim SJ, Kim HJ, Kim NK. Progesterone assays as an aid for improving reproductive efficiency in dairy cattle. V. Plasma progesterone determination as applied to the differential diagnosis of reproductive disorders and judgement of treatment responses to PGF2 $\alpha$ or GnRH treatment. Korean Journal of Veterinary Research 1995; 36: 603-613 (in Korean).

25. Roche JF. Control of oestrus in cattle. World Review of Animal Production 1979; 15: 49-76.

26. Viseshakul $\mathbf{N}$, Srikosak $\mathbf{W}$, Pisanasarakit $\mathbf{P}$, Chantarapateep P, Lohachit C, Poomsuwan P. Thai Journal of Veterinary Medicine 1986; 16: 88-99.

27. Savio JD, Thatcher WW, Badinga L, de la Sota RL, Wolfenson D. Regulation of dominant follicle turnover during the oestrous cycle in cows. J Reprod Fert 1993; 97: 197-203.

28. Stock AE, Fortune JE. Ovarian Follicular Dominance in cattle: Relationship between prolonged growth of the ovulatory follicle and endocrine parameters. Endocrinlogy 1993; 132: 11081114. 